\title{
RANCANG BANGUN SISTEM INFORMASI PENJUALAN OBAT DI APOTEK ERA MEDIKA BERBASIS WEBSITE
}

\author{
I Gede Feby Dian Pramana Putra ${ }^{1)}$, I Gede Putu Krisna Juliharta ${ }^{2)}$, Anak Agung Istri Ita Paramitha ${ }^{3)}$ \\ ${ }^{1)}$ Sistem Informasi, STMIK Primakara \\ email: febidianpramana@gmail.com \\ ${ }^{2)}$ Sistem Informasi, STMIK Primakara \\ email: krisna@primakara.ac.id \\ 3) Sistem Informasi, STMIK Primakara \\ email: ita@primakara.ac.id
}

\begin{abstract}
Handling data by doing this manually has a number of obstacles at the Era Medika Pharmacy, including causing errors in checking drug stock once a week, inaccurate recording of incoming or outgoing drug stocks so that there is a mistake in recording the final stock, as well as the results of sales reports use paper. To overcome this problem the drug sales information system is a solution to the drug sales process, and uses the Click to Chat API Whatsapp to facilitate sending messages to drug suppliers. To obtain the data needed during the study, the author uses several method including: interviews, observation, and literature studies. The data obtained then analyzes using the Waterfall method. The results of this study conducted on testing sales applications that have been designed can help to facilitate managers in the sales process that can be accessed online so that it can work effectively and efficiently. With the Click to Chat feature Whatsapp can facilitate messages to drug suppliers according to the contact you want to reach. The results of this study are expected to be useful in the future.
\end{abstract}

Keywords: Information System, Sales, Website, Click to Chat Whatsapp.

\section{PENDAhuluan}

\subsection{Latar Belakang}

Teknologi informasi salah satu teknologi yang berkembang sangat cepat pada saat ini, penggunaan alat bantu komputer atau pembuatan aplikasi sebagai salah satu sarana penunjang dalam sistem informasi dapat memberikan hasil lebih baik dan akurat untuk output sebuah sistem, tentu bila sistem di dalamnya telah berjalan dengan baik dan sesuai dengan yang diinginkan oleh user.

Apotek Era Medika adalah tempat perusahaan jenis obat-obatan seperti kapsul, sirup, dan berbagai jenis obat lainnya yang telah berdiri pada tahun 1999 hingga sekarang yang beralamat di Jalan A.Yani Utara No.323, Peguyangan, Denpasar, Bali. Mengenai masalah penjualan obat di Apotek Era Medika berdasarkan hasil wawancara dan observasi dengan manajer Apotek Era Medika dalam pengolahan datanya masih dilakukan secara manual. Penanganan data dengan melakukan secara manual ini mempunyai beberapa kendala, diantaranya menyebabkan terjadinya kesalahan dalam proses rekapan penjualan obat, pengecekan stok obat yang dilakukan sebulan sekali, serta hasil laporan penjualan dalam menggunakan kertas sehingga perlu dibuatkan sistem mengatasi masalahmasalah pada Apotek Era Medika. Whatsapp adalah aplikasi instan yang dilihat dari fungsinya hampir sama dengan aplikasi Untuk mengatasi masalah tersebut, sistem informasi penjualan obat diharapkan semua obat-obat yang sudah terjual dapat diketahui dengan jelas tanpa adanya kesalahan-kesalahan yang sifatnya menganggu dalam proses penjualan obat nantinya, serta untuk memesan obat tertentu ke supplier obat akan 
dikembangkan berbasis website dengan fitur tambahan API Whatsapp yaitu Click to Chat.

Sistem informasi penjualan obat menggunakan Javascript serta database menggunakan MySQL. Dampak hasil sistem ini adalah untuk mempercepat proses pembuatan laporan penjualan obat dalam setiap periode tertentu ${ }^{[1]}$

\subsection{Sistem Informasi}

Sistem adalah kumpulan orang yang saling bekerja sama dengan ketentuanketentuan aturan yang sistematis dan terstruktur untuk membentuk satu kesatuan yang melaksanakan suatu fungsi untuk mencapai tujuan, sedangkan informasi adalah data yang diolah menjadi lebih berguna dan berarti bagi penerimanya, serta untuk mengurangi ketidakpastian dalam proses pengambilan keputusan mengenai suatu keadaan. Sistem informasi merupakan suatu kombinasi teratur dari orang-orang, hardware, software, jaringan komunikasi dan sumber daya data yang mengumpulkan, mengubah, dan menyebarkan informasi dalam sebuah organisasi. ${ }^{[2]}$

\subsection{Penjualan}

Penjualan adalah proses yang menyebabkan penjual menentukan dan melakukan serta memuaskan kebutuhan atau keinginan pembeli atau pelanggan untuk saling menghasilkan keuntungan antara penjual atau pembeli. ${ }^{[3]}$

\subsection{Website}

Website adalah keseluruhan halamanhalaman web yang terdapat dalam sebuah domain yang mengandung informasi. Sebuah website biasanya dibangun atas banyak halaman web yang saling berhubungan. Hubungan antara satu halaman web dengan web yang lainnya disebut hyperlink, sedangkan teks yang dijadikan media penghubung disebut hypertext. ${ }^{[4]}$

\subsection{Whatsapp Click to Chat}

Click to Chat merupakan fitur Whatsapp yang memungkinkan kita untuk melakukan chat di Whatsapp tanpa harus terlebih dahulu menyimpan nomor seseorang pada handphone milik kita sebagaimana lazimnya. Hanya dengan melakukan klik pada link, seseorang akan diarahkan langsung ke aplikasi Whatsapp pada ponsel maupun Whatsapp versi web, menyesuaikan darimana ia melakukan klik.

\section{METODE PENELITIAN}

\subsection{Metode Penelitian}

Metode penelitian ini penulis akan menggunakan metode waterfall yang mengarah pada hasil penelitian dengan tujuan yang ingin dicapai, dengan mengolah berbagai data dan informasi yang diperoleh dari wawancara pada penjualan obat di Apotek Era Medika, dan melakukan observasi tentang gejala yang ada. Berikut gambar dari metode waterfall adalah sebagai berikut:

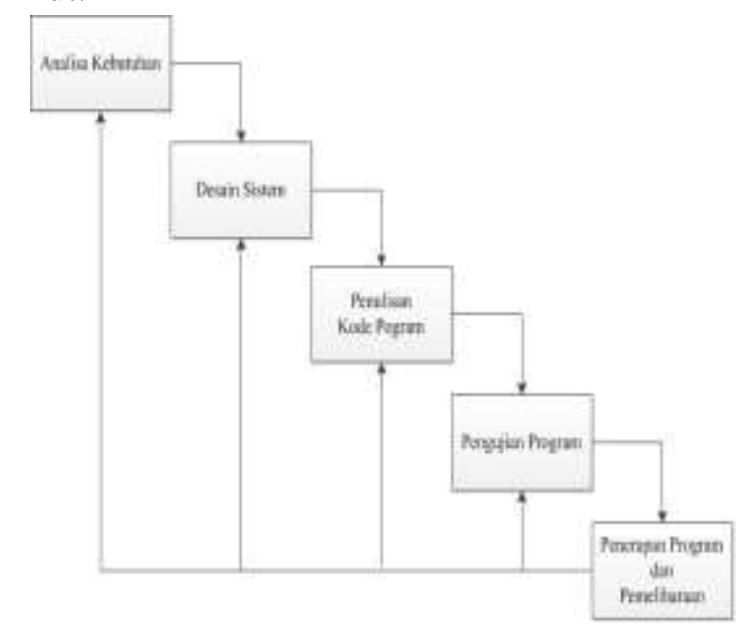

Gambar 1. Metode Waterfall

Ada 5 tahapan dari metode waterfall, yaitu (1) analisa kebutuhan; (2) desain sistem; (3) penulisan kode program; (4) pengujian program; (5) penerapan program dan pemeliharaan. Metode ini merupakan metode yang sering digunakan oleh penganalisa sistem pada umumnya. Inti dari metode waterfall adalah dengan pengerjaan dari satu sistem dilakukan secara berurutan atau secara linear. 
Jadi setiap tahap harus diselesaikan terlebih dahulu secara penuh sebelum diteruskan ke tahap berikutnya untuk menghindari terjadinya pengulangan tahapan. ${ }^{[5]}$

\subsection{Alat dan Bahan}

Adapun alat dan bahan yang digunakan dalam penelitian ini sebagai berikut:

a. Perangkat keras (Hardware) berupa laptop dengan spesifikasi; Processor Intel Atom x5-Z8350 with Intel HD Graphics $1.44 \mathrm{GHz}$ RAM 2GB dan beberapa perangkat keras pendukung lainnya.

b.Perangkat lunak (Software) antara lain sistem operasi Windows 10 Ultimate 64-bit, XAMPP, Google Chrome, bahasa pemrograman PHP dan Javascript, untuk basis data menggunakan MySQL.

\subsection{Teknik Pengumpulan Data}

Adapun teknik atau cara pengumpulan data yang dilakukan penulis adalah sebagai berikut:

1. Penelitian Langsung (Field Research)

Penelitian Langsung atau Field Research merupakan penelitian yang dilakukan dengan mengumpulkan data informasi yang diperoleh langsung dari responden dan mengamati secara langsung. Penelitian ini dilakukan terhadap kegiatan dari seluruh objek penelitian yang meliputi:

a. Observasi

Penelitian ini melakukan observasi langsung mengenai proses penjualan di Apotek Era Medika.

b. Wawancara

Pada penelitian ini penulis melakukan wawancara dengan sumber yang mengerti tentang proses penjualan pada Apotek Era Medika yaitu Drs. I Made Darmawan, APT. Adapun hal yang berkaitan dengan wawancara mengenai sejarah apotek, serta kendala-kendala yang dialami selama bekerja dengan menggunakan secara manual.

2. Studi Pustaka

Studi pustaka adalah teknik pengumpulan data dari berbagai bahan pustaka (referensi) berupa buku dan jurnal yang relevan dan mempelajari yang berkaitan dengan masalah yang akan dibahas peneliti.

\subsection{Tempat \& Waktu Penelitian}

Penelitian ini dilakukan di Apotek Era Medika yang beralamat di Jl. A.Yani Utara No.323, Peguyangan, Denpasar, Bali. Periode penelitian ini dilaksanakan selama bulan Maret sampai dengan Mei 2018.

\subsection{Alur Penelitian}

Alur detail penelitian dapat dilihat pada gambar dibawah ini: 


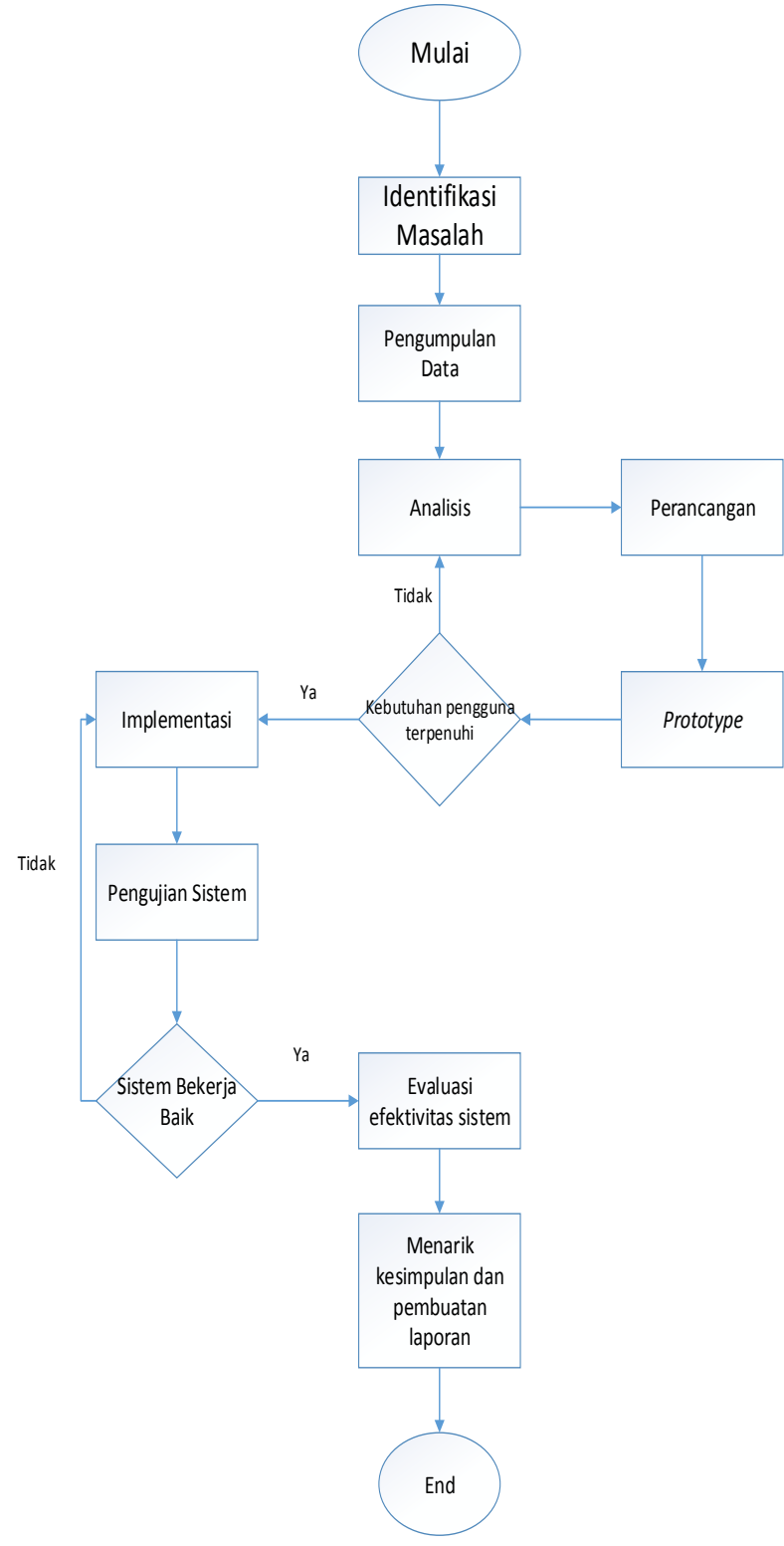

\section{Gambar 2. Alur Penelitian}

Penjelasan dari alur penelitian pada gambar diatas adalah sebagai berikut:

a. Kebutuhan fungsional sistem: Tahap ini adalah kebutuhan yang berisi proses-proses apa saja yang nantinya dilakukan oleh sistem. Adapun beberapa kebutuhan fungsional sistem adalah sebagai berikut:

1) Admin dapat mengelola data barang obat

2) Admin dapat mengelola stok obat

3) Admin dapat mengelola transaksi penjualan

4) Admin dapat mengelola nota penjualan

5) Admin dapat mengelola supplier obat

6) Admin dapat mengelola order ke supplier obat
7) Sistem dapat menampilkan hasil laporan penjualan obat secara keseluruhan

8) Sistem dapat menampilkan nota laporan penjualan

b. Desain Sistem : Tahap ini membuat desain sistem menggunakan Data Flow Diagram (DFD).

c. Rancang Bangun Sistem : Tahap ini membangun sebuah aplikasi berbasis website dengan bahasa pemrograman PHP dan Javascript, serta MySQL sebagai database.

d. Pengujian Sistem : Tahap ini melakukan pengujian pada aplikasi dengan menggunakan black box testing. Black Box Testing ini akan menguji kelayakan sistem, sehingga diketahui layak atau tidaknya sistem untuk diimplementasikan.

e. Implementasi Sistem : Tahap ini melakukan wawancara guna untuk mengetahui aplikasi yang dibuat sudah sesuai dengan apa yang diharapkan oleh Apotek Era Medika.

f. Analisa Dampak Sistem : Tahap ini adalah tahap dari hasil wawancara yang telah dilakukan.

\subsection{Model Pengembangan Sistem}

Tahapan pemodelan pengembangan Sistem Informasi Penjualan Obat Pada Apotek Era Medika Berbasis Website yang akan diusulkan dalam bentuk Data Flow Diagram (DFD). Data Flow Diagram (DFD)

Data Flow Diagram (DFD) adalah suatu model logika data atau proses yang dibuat lebih mendetail dibanding diagram konteks yang diperbolehkan, bisa dicapai dengan mengembangkan diagram. ${ }^{[6]}$

\section{a. DFD Level 0 / Diagram Konteks}

Berikut ini adalah gambar diagram konteks yang diusulkan sebagai berikut: 


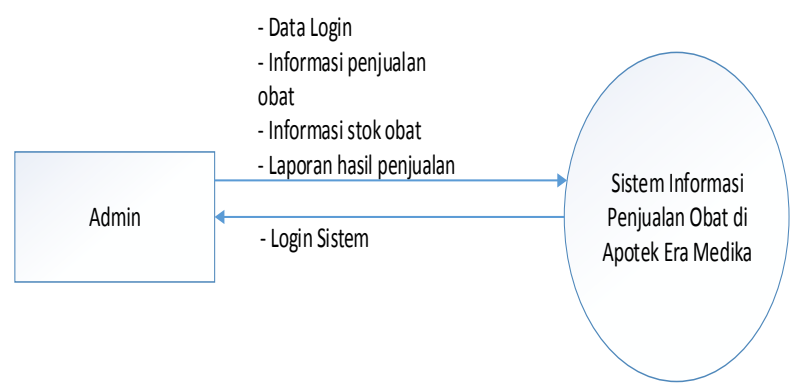

Gambar 3. DFD Level 0 / Diagram Konteks

b. DFD Level 1

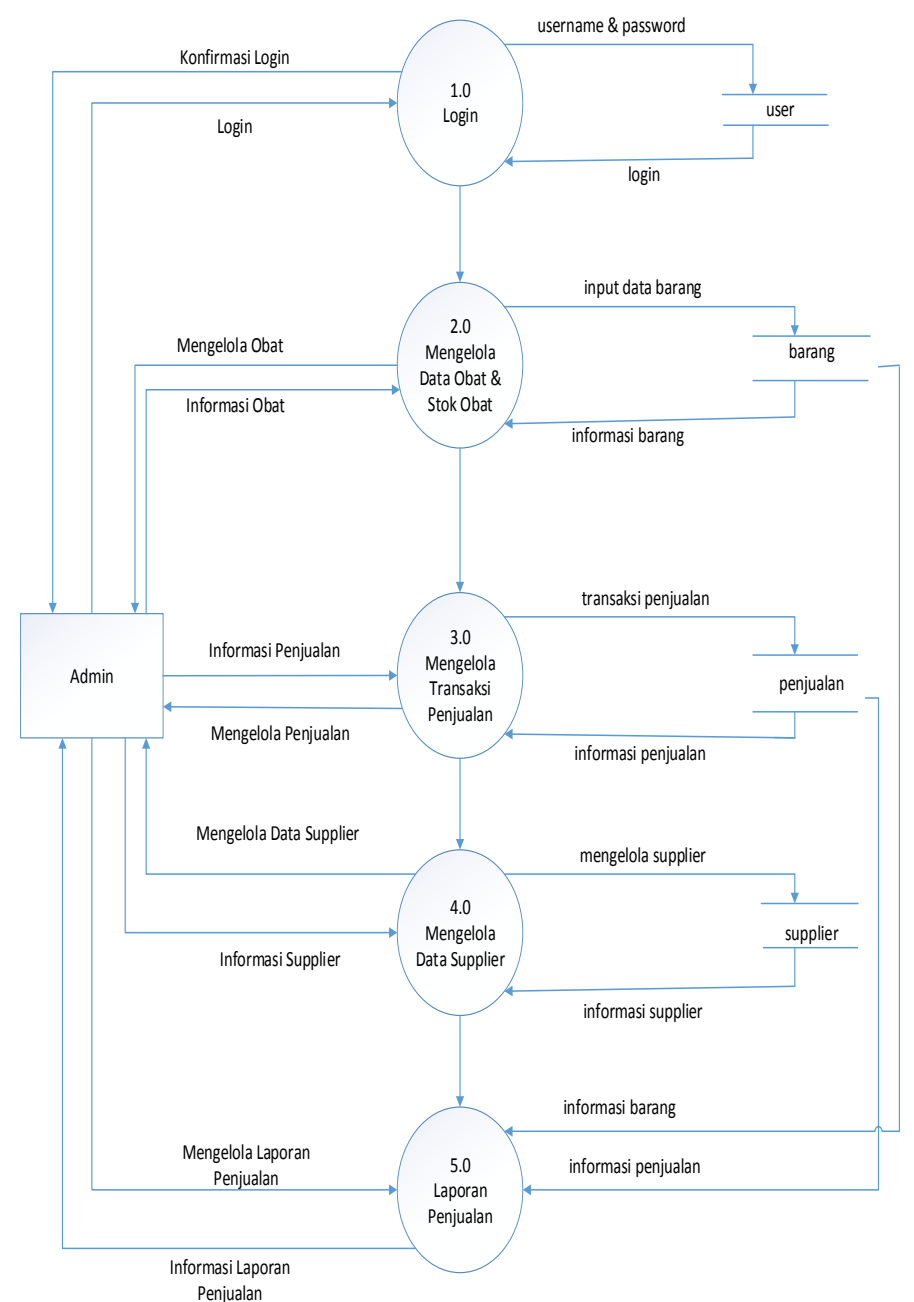

Gambar 4. DFD Level 1

\section{c. DFD Level 2 Login}

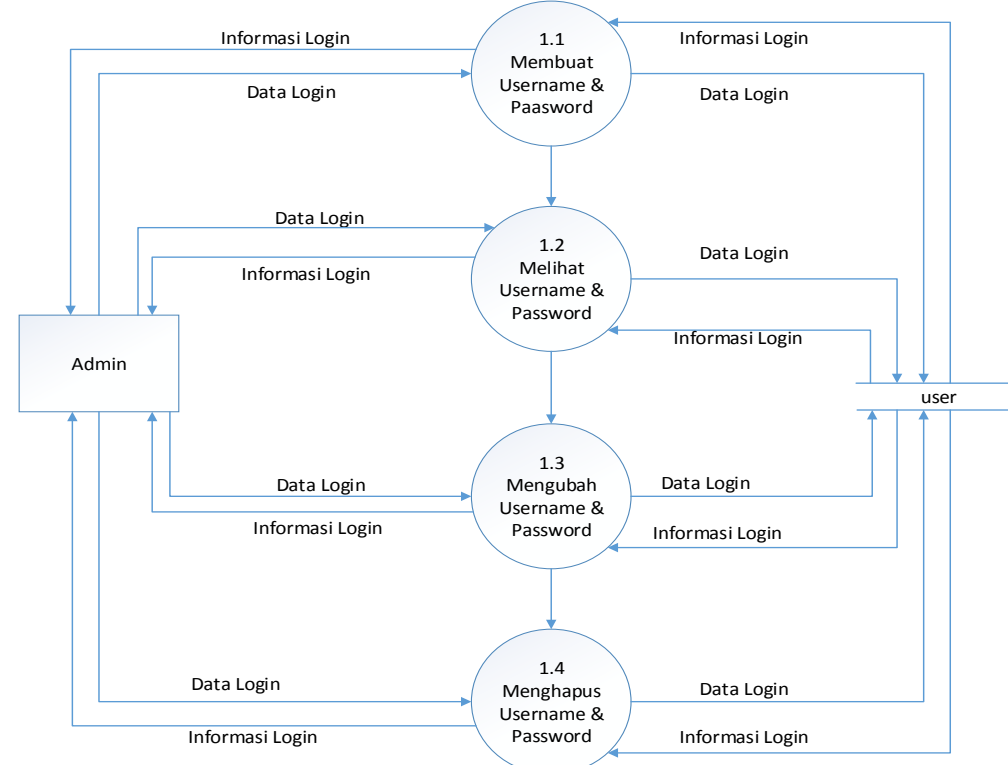

Gambar 5. DFD Level 2 Login

\section{d. DFD Level 2 Mengelola Obat}

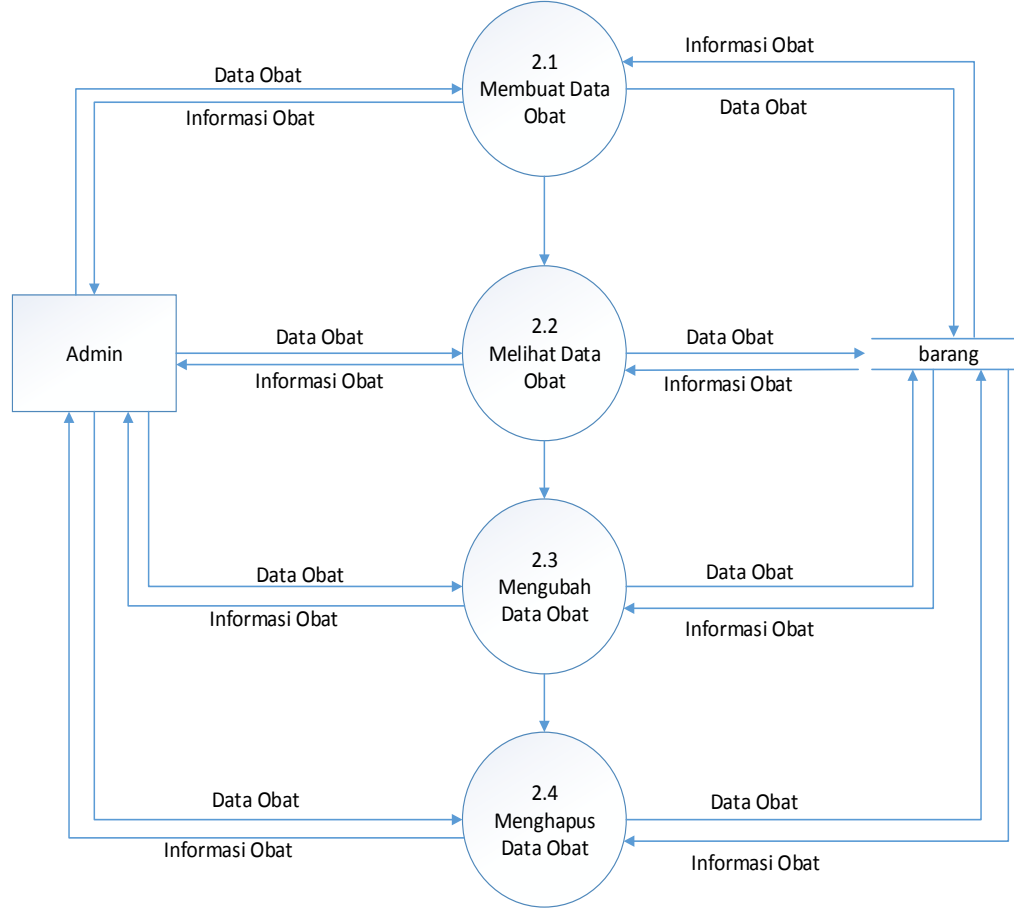

Gambar 6. DFD Level 2 Mengelola Obat 


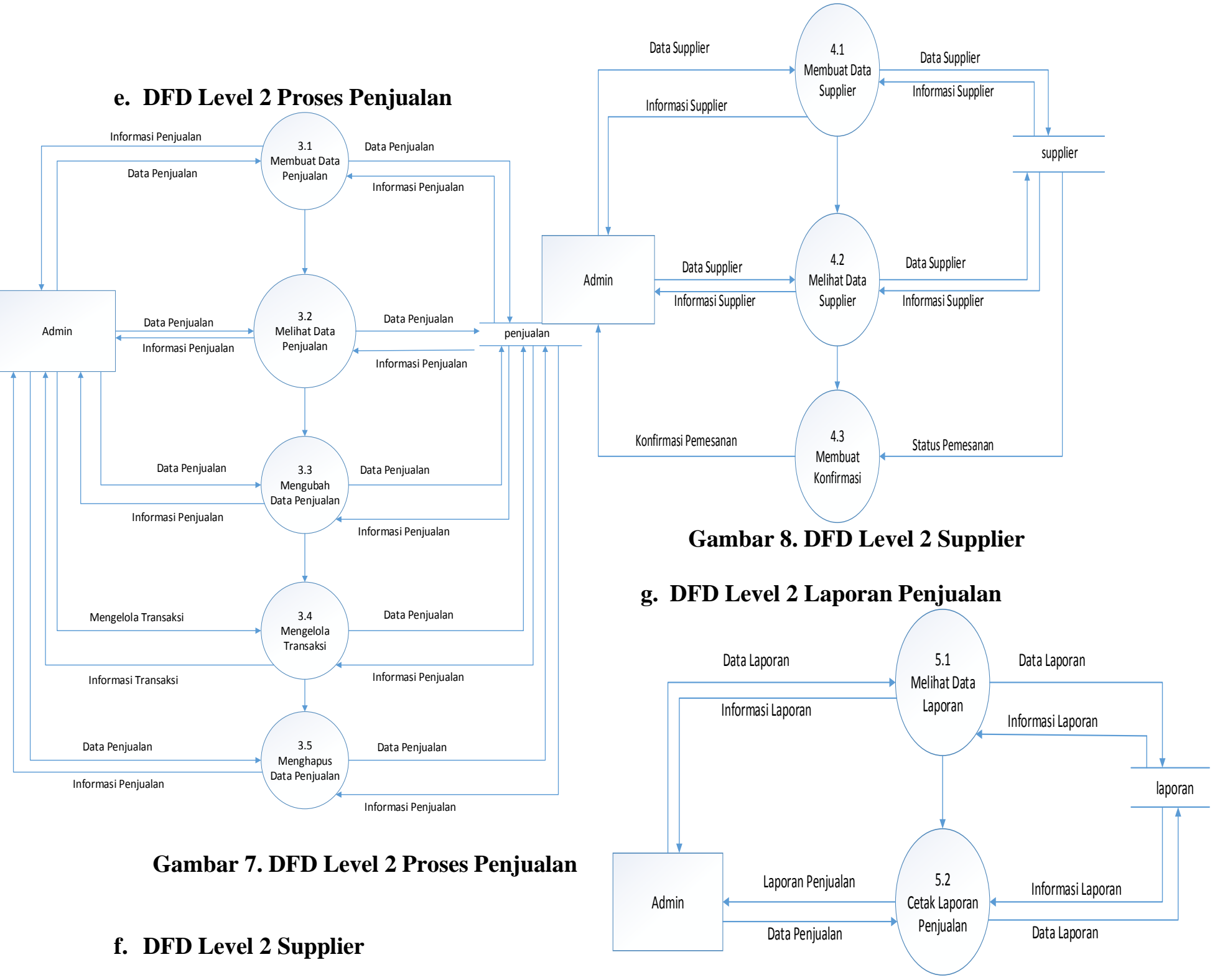

Gambar 9. DFD Level 2 Laporan Penjualan

\section{h. Flowchart}

Flowchart menggambarkan urutan logika dari suatu prosedur pemecahan masalah, sehingga flowchart merupakan langkah-langkah penyelesaian masalah yang dituliskan dalam simbol-simbol tertentu. [7] Berikut ini adalah gambar flowchart sistem yang diusulkan sebagai berikut: 


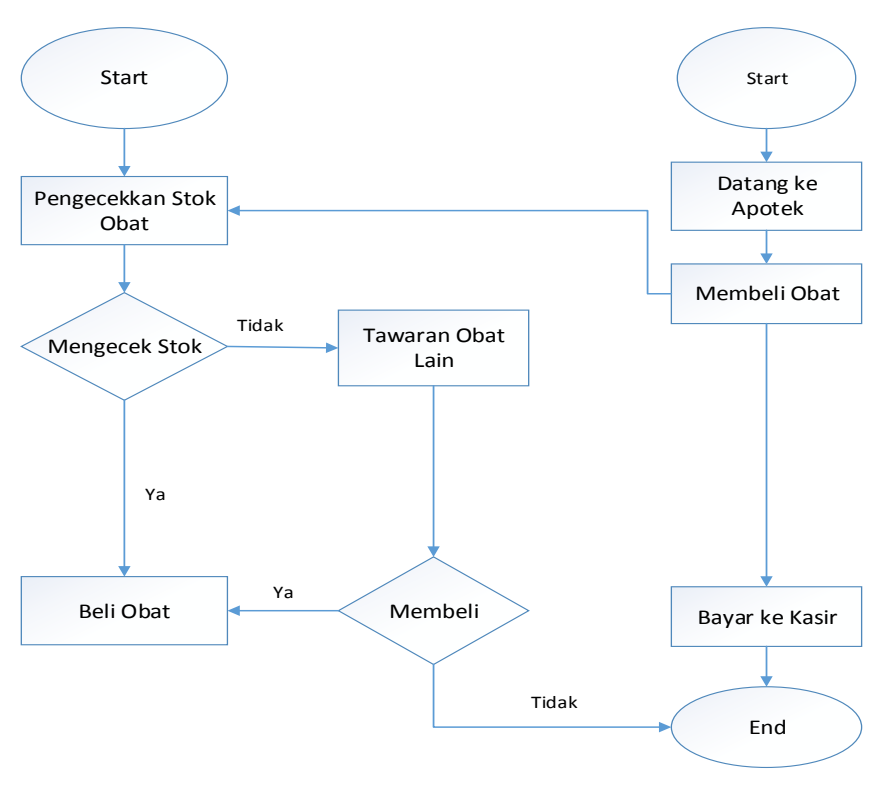

Gambar 10. Flowchart sistem yang diusulkan

\section{i. ERD (Entity Relationship Diagram)}

Entity Relationship Diagram (ERD) adalah model konseptual yang mendeskripsikan hubungan antara penyimpanan (dalam DFD). ERD digunakan untuk memodelkan struktur data dan hubungan antar data. ${ }^{[8]}$

Berikut ini adalah gambar ERD sistem yang diusulkan sebagai berikut:

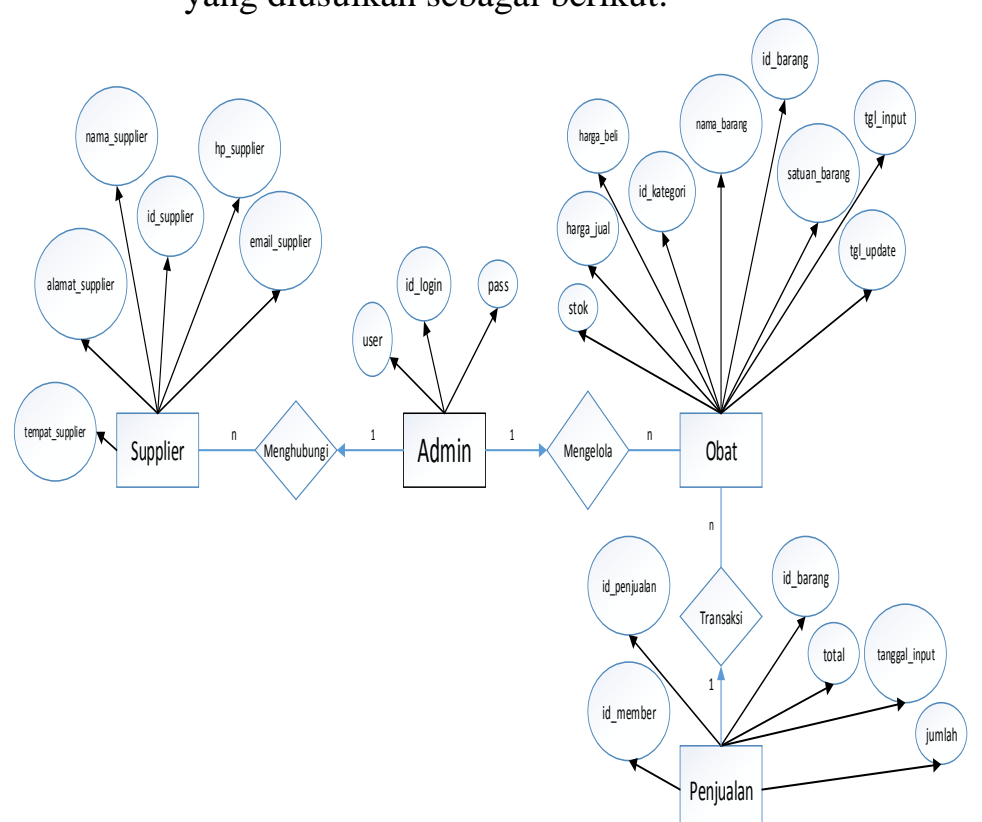

Gambar 11. ERD (Entity Relationship Diagram)

Dalam gambar ERD tersebut ada beberapa entitas diantaranya Admin, Obat, Penjualan, dan Supplier.

\section{HASIL DAN PEMBAHASAN}

a. Halaman Login

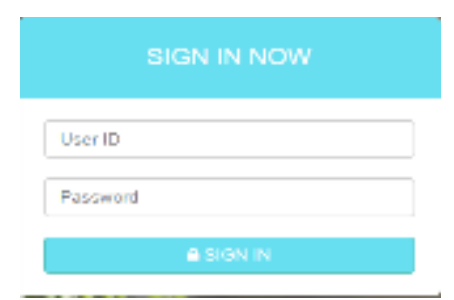

\section{Gambar 12. Halaman Login}

Pada gambar halaman login berisikan Username dan Password yang digunakan untuk akses masuk sebagai admin apotek. Dengan cara user akan memasukkan Username dan Password admin setelah sudah akan muncul menu apotek.

\section{b. Halaman Tampilan Menu}

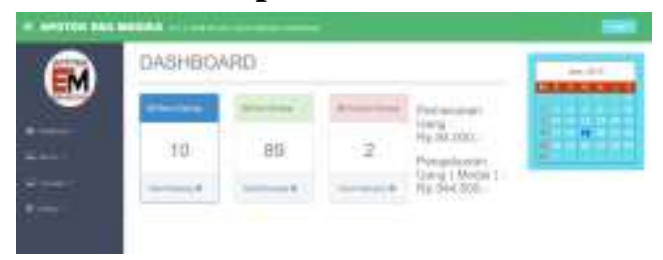

Gambar 13. Halaman Tampilan Menu

Pada gambar halaman tampilan menu dimana setelah login akan muncul tampilan awal halaman menu.

\section{c. Halaman Barang Obat}

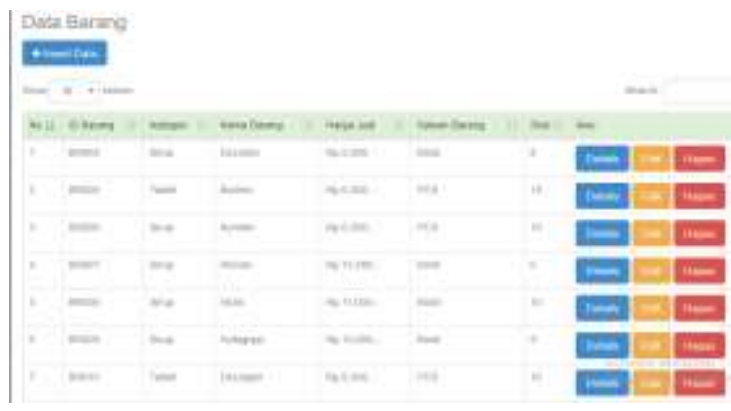

Gambar 14. Halaman Barang Obat

Pada gambar halaman barang obat dimana tampilan tersebut berisi barang obat yang tersedia di apotek. 


\section{d. Tambah Barang Baru}

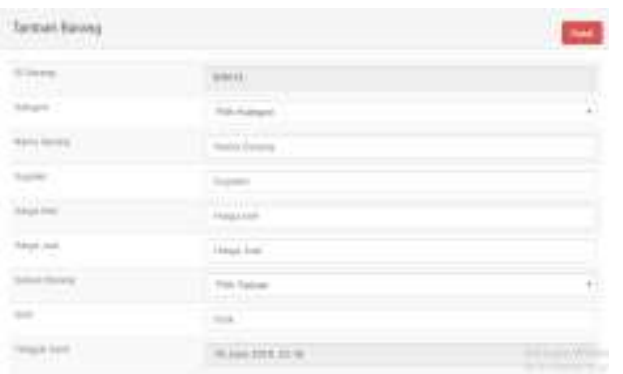

Gambar 15. Tambah Barang Baru

Pada gambar tambah barang baru berisikan Nama Obat, Jenis, Supplier, Harga Beli, Harga Jual, Jumlah, dan Tanggal Input. Ketika barang obat masuk akan menginput di bagian tambah barang baru.

\section{e. Halaman Detail Barang}

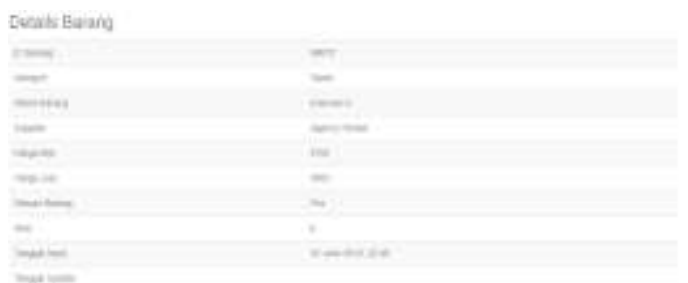

\section{Gambar 16. Halaman Detail Barang}

Pada gambar halaman detail barang ketika barang obat yang tersedia di Apotek Era Medika sudah sesuai.

\section{f. Halaman Edit Barang}

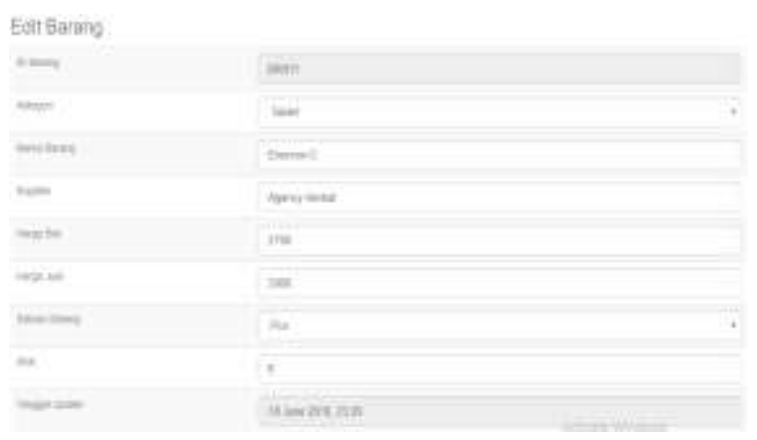

\section{Gambar 17. Halaman Edit Barang}

Pada gambar halaman edit barang ketika ingin edit barang obat seperti supplier, jumlah, dan tanggal masuk. Misalkan, ketika barang obat yang sama tapi jumlah yang berbeda, admin bisa mengedit jumlah obat tersebut.

\section{g. Halaman Transaksi}

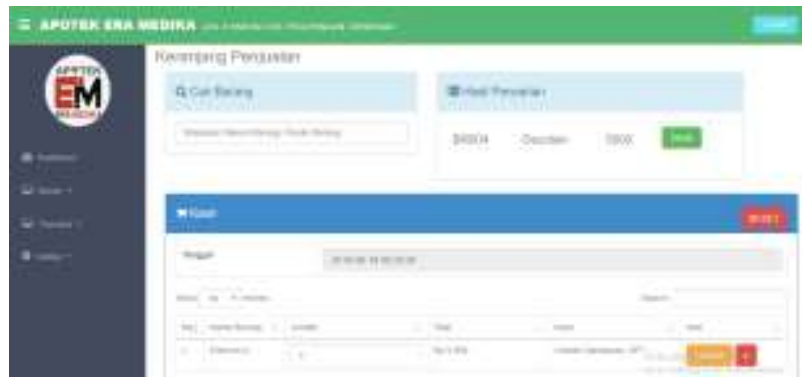

Gambar 18. Halaman Transaksi

Pada gambar halaman transaksi ketika pelanggan sudah membeli obat sesuai yang diinginkan. Hanya mengetik nama barang obat yang ingin beli lalu mengecek hasil barang, jika ada maka akan melakukan proses transaksi.

\section{h. Nota Penjualan}

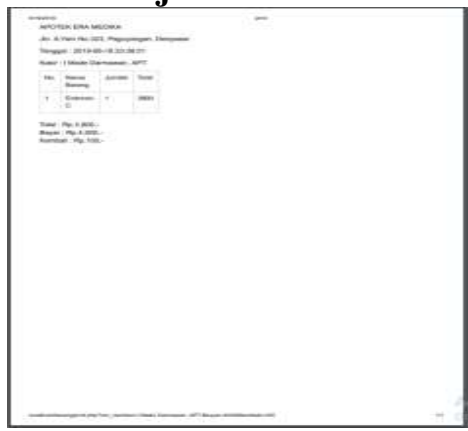

Gambar 19. Nota Penjualan

Pada gambar nota penjualan ketika menyelesaikan proses transaksi penjualan sehingga pembeli membutuhkan nota penjualan tersebut.

\section{i. Halaman Supplier}

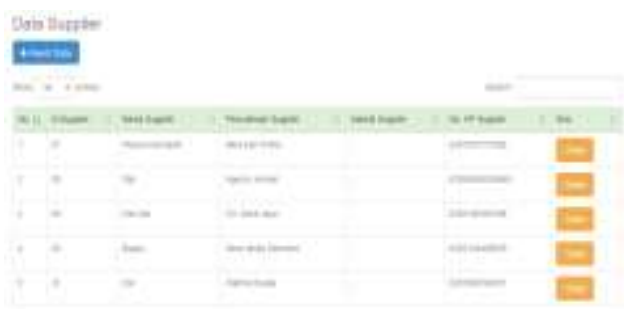

Gambar 20. Halaman Supplier

Pada gambar halaman supplier ketika manajer mengirim pesan kepada supplier setelah barang obat habis. Mengirim pesan tersebut menggunakan fitur Click to Chat Whatsapp. Dengan cara admin akan mencari 
kontak supplier yang ada di halaman supplier lalu kirim pesan untuk order barang obat.

\section{j. Halaman Web Whatsapp}

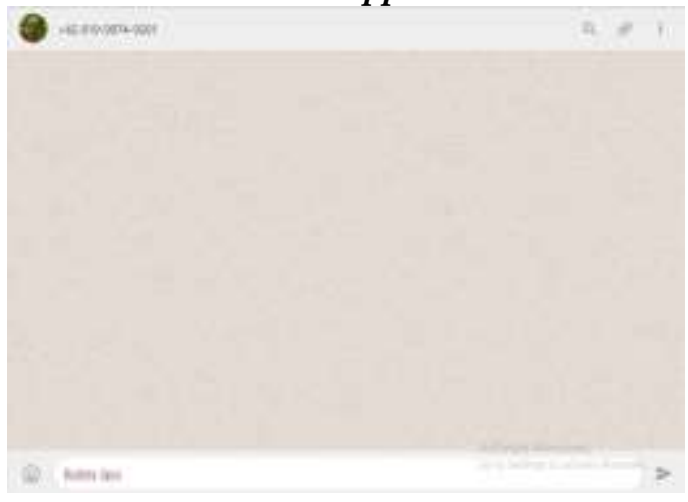

Gambar 21. Halaman Web Whatsapp

Pada gambar halaman Web Whatsapp ketika manajer melakukan klik pada kontak yang dikirim, manajer yang akan mengarahkan langsung ke Web Whatsapp pada kontak yang dituju.

\section{k. Halaman Laporan Penjualan}

\section{Gambar 22. Halaman Laporan Penjualan}

Pada gambar halaman laporan penjualan ketika manajer mengecek hasil penjualan tiap bulan sehingga bisa mengecek hasil penjualan yang detail dan juga sisa barang obat tersebut.

\section{Nota Laporan Penjualan}

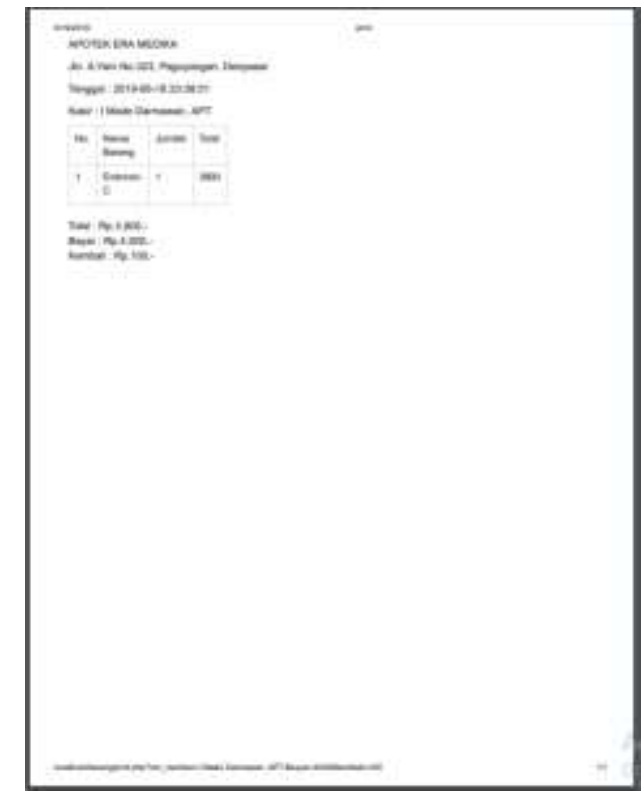

Gambar 23. Nota Laporan Penjualan

Pada gambar nota laporan penjualan ketika manajer memproses rekap laporan hasil penjualan.

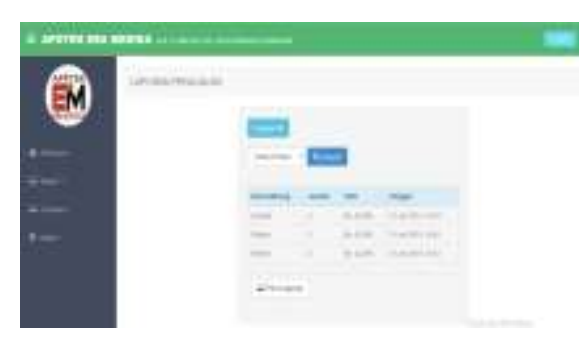

k. Black Box Testing

Black Box Testing adalah metode dimana penguji atau tester hanya mengetahui apa yang harus dilakukan suatu software. Penguji tidak mengetahui bagaimana software tersebut beroperasi. Jadi penguji hanya menerima hasil dari apa yang dimasukkan tanpa mengetahui bagaimana atau mengapa bisa demikian.

PENGUJIAN BLACK BOX TESTING

\begin{tabular}{|c|l|l|c|}
\hline No. & Skenario & \multicolumn{1}{|c|}{$\begin{array}{l}\text { Hasil yang } \\
\text { diharapkan }\end{array}$} & Hasil \\
\hline 1. & $\begin{array}{l}\text { Form } \\
\text { Login }\end{array}$ & Masuk menu utama & Berhasil \\
\hline 2. & $\begin{array}{l}\text { Halaman } \\
\text { barang } \\
\text { obat }\end{array}$ & $\begin{array}{l}\text { Menampilkan } \\
\text { barang obat yang } \\
\text { tersedia }\end{array}$ & Berhasil \\
\hline 3. & $\begin{array}{l}\text { Input } \\
\text { barang } \\
\text { baru }\end{array}$ & $\begin{array}{l}\text { Sistem input barang } \\
\text { yang baru }\end{array}$ & Berhasil \\
\hline 4. & Halaman & Menampilkan detail & Berhasil \\
\hline
\end{tabular}




\begin{tabular}{|c|c|c|c|}
\hline & $\begin{array}{l}\text { Detail } \\
\text { Barang }\end{array}$ & $\begin{array}{l}\text { barang obat yang } \\
\text { sesuai tersedia }\end{array}$ & \\
\hline 5. & $\begin{array}{l}\text { Halaman } \\
\text { Edit } \\
\text { Barang }\end{array}$ & $\begin{array}{l}\text { Sistem melakukan } \\
\text { edit barang obat }\end{array}$ & Berhasil \\
\hline 6. & $\begin{array}{l}\text { Halaman } \\
\text { Transaksi }\end{array}$ & $\begin{array}{l}\text { Menampilkan } \\
\text { halaman transaksi } \\
\text { setelah pelanggan } \\
\text { melakukan } \\
\text { pembelian obat }\end{array}$ & Berhasil \\
\hline 7. & $\begin{array}{l}\text { Nota } \\
\text { Penjualan }\end{array}$ & $\begin{array}{l}\text { Menampilkan nota } \\
\text { penjualan setelah } \\
\text { proses transaksi } \\
\text { selesai }\end{array}$ & Berhasil \\
\hline 8. & $\begin{array}{l}\text { Halaman } \\
\text { Supplier }\end{array}$ & $\begin{array}{l}\text { Menampilkan } \\
\text { kontak supplier yang } \\
\text { akan mengirim } \\
\text { pesan menggunakan } \\
\text { fitur Click to } \text { Chat }\end{array}$ & Berhasil \\
\hline 9. & $\begin{array}{l}\text { Halaman } \\
\text { Web } \\
\text { Whatsapp }\end{array}$ & $\begin{array}{l}\text { Sistem menuju } \\
\text { halaman web } \\
\text { Whatsapp ketika } \\
\text { sudah memilih } \\
\text { kontak yang akan } \\
\text { dituju }\end{array}$ & Berhasil \\
\hline 10. & $\begin{array}{l}\text { Halaman } \\
\text { Laporan } \\
\text { Penjualan }\end{array}$ & $\begin{array}{l}\text { Menampilkan } \\
\text { halaman laporan } \\
\text { penjualan ketika } \\
\text { mengecek hasil } \\
\text { penjualan tiap bulan }\end{array}$ & Berhasil \\
\hline 11. & $\begin{array}{l}\text { Nota } \\
\text { Laporan } \\
\text { Penjualan }\end{array}$ & $\begin{array}{l}\text { Sistem sedang } \\
\text { memproses setelah } \\
\text { mengecek hasil } \\
\text { laporan penjualan }\end{array}$ & Berhasil \\
\hline
\end{tabular}

\section{REFERENSI}

[1] Utami and Purnama, "Pembangunan Sistem Informasi Penjualan Obat Pada Apotek Punung", vol. 1, no. 1, p. 7, 2014.

[2] E.Y. Anggreni, Pengantar Sistem Informasi. Yogyakarta, 2017.

[3] A. Iskandar and A.H. Rangkuti, "Perancangan Sistem Informasi Penjualan Tunai Pada Pt. Klaten Bercahaya", vol.3, no. 2, p. 8, 2008.

[4] Yuhefizar, Mooduto, and R. Hidayat, Cara Mudah Membangun Website Interaktif Menggunakan Content Management System Joomla. Jakarta, 2008.

[5] Lesmono, "Rancang Bangun Sistem Informasi Penjualan Sepatu Berbasis Website Dengan Metode Waterfall", vol. 6, no. 1, 2018.

[6] Afyenni, "Perancangan Data Flow Diagram Untuk Sistem Informasi Sekolah (Studi Kasus Pada Sma Pembangunan Laboratorium Unp)", vol. 2, no. 1, p. 5, 2014.

[7] Sitorus, Algoritma dan Pemrograman. Yogyakarta, 2015.

[8] A.T. Wibowo, "Pembuatan Aplikasi eCommerce Pusat Oleh-Oleh Khas Pacitan Pada Toko Sari Rasa Pacitan", vol. 2, no. 4, 2012.

\section{KESIMPULAN}

Proses penjualan obat di Apotek Era Medika sebelumnya masih menggunakan metode manual. Pengolahan data nya belum menggunakan sistem informasi yang berbasis komputer. Dengan sistem informasi ini mampu mengatasi permasalahan yang ada proses penjualan obat sebelumnya sehingga akan menambah kinerja dalam pengelolaan penjualan menjadi lebih baik, efektif, dan efisien. Adapun kesimpulan yang didapatkan dalam merancang sistem ini dengan pengujian metode Black Box Testing didapatkan hasil bahwa Sistem Informasi Penjualan Obat di Apotek Era Medika Berbasis Website sudah sesuai yang diharapkan sistem dapat memberikan informasi tentang penjualan obat pada Apotek Era Medika. 